\title{
A Preliminary Study on Oral Performances of English learners in L1 and L2
}

\author{
Meral Melek Ünver \\ Anadolu University, Turkey \\ mmunver@anadolu.edu.tr
}

\author{
Belgin Aydin \\ Anadolu University, Turkey \\ baydin@anadolu.edu.tr
}

\author{
Şener Eş \\ Anadolu University, Turkey \\ senere@ anadolu.edu.tr
}

\begin{abstract}
$^{1}$
Performing well in oral examinations is a great challenge for language learners in EFL contexts because test takers have many linguistic concerns while performing let alone thinking of what to say. In our context, School of Foreign Languages, Anadolu University, Turkey, our students mostly perform poorly in speaking exams, claiming that they would perform better if it were in Turkish. Thus, the question arises whether it is learners' linguistic incapability or lack of topical knowledge, which prevents them from performing. This study aims to investigate how Turkish learners of English (N=35; 18-B1 and 17-B2 Level) would perform if they were given the same oral test in L1, and compares the scores they got from L2 and in L1 to see if their performance differs and if proficiency level is a variable for this difference. The analysis of the quantitative data collected through oral interviews reveals that the learners' performance was a lot better in L1; and B2 level students performed well in both languages while B1 level learners performed significantly better in L1. The qualitative data from interviews and the survey shows how learners reflect on the exam process and their performance.
\end{abstract}

Keywords: Oral performance assessment, testing speaking, L1 performance, L2 performance

\begin{abstract}
$\ddot{O} \mathbf{z}$
İngilizcenin yabancı dil olarak öğrenildiği ortamlarda öğrencilerin karşılaştığı en büyük zorluklarından biri İngilizce konuşma sınavlarında iyi bir performans sergileyememektir. Sadece ne söyleyeceğini düşünmek değil, aynı zamanda doğru yapıları kullanmak, uygun kelimeleri seçmek ve düşüncelerini doğru bir telaffuzla aktarmak sınava giren öğrencilerin dikkate alması gereken unsurlardan bir kaçıdır. Anadolu Üniversitesi Yabancı Diller Yüksekokulunda öğrencilerimiz genellikle konuşma sınavlarında ortalama ya da ortalamanın altında performans sergilemekte ve bu konuşmayı Türkçe'de yapmaları istense daha başarılı olacaklarını iddia etmektedirler. Bu bağlamda öğrencilerin performansını etkileyen faktörün konuyla ilgili bilgileri mi yoksa dil becerileri mi olduğu sorusunu akla getiriyor. Bu çalışmanın amacı, İngilizce öğrenen Türk öğrencilerinin İngilizce ve Türkçe olarak aynı soru ve konularda konuşma performanslarını ölçmektir. Çalışmada 18'i B1 ve 17'si B2 seviyesinde olan 35 İngilizce öğrencisinin hem İngilizce hem de Türkçe
\end{abstract}

${ }^{1}$ Araştırma makalesi, İlk gönderim tarihi: 21.06.2016 Kabul tarihi: 22.07.2016 


\begin{abstract}
konuşma sınavındaki performanslarından aldıkları notları karşılaştırılmaktadır. Değerlendirme sözlü performanslar için geliştirilen kurumsal kriter kullanılmıştır. Alınan notlar İngilizce ve Türkçe'de performansların farklılık gösterip göstermediğini ve bu farkın dil seviyesiyle ilgili olup olmadığını anlamak amacıyla karşılaştırılmıştır. Öğrencilerin sınav süreci ve kendi performanslarıyla ilgili görüşleri, uygulama sonrasında öğrencilerle yapılan görüşmeler ve online ankete verdikleri cevaplarla elde edilmiştir. Sayısal veri sonuçları öğrencilerin Türkçe'de daha iyi performans sergilediklerini göstermiştir. Ayrıca B2 seviyesindeki öğrencilerin her iki dilde de performanslarının iyi olduğu, ancak B1 seviyesindeki öğrencilerin kendi dillerinde İngilizce'de olduğundan daha iyi oldukları gözlemlenmiştir. Değerlendirmede kullanılan kriterdeki her bir bölüm ayrı ayrı değerlendirildiğinde, öğrencilerin Türkçe ve İngilizce performanslarına verilen notlar arasında belirgin bir farklılık olmadığı saptanmıştır.
\end{abstract}

Anahtar Kelimeler: Sözlü sınav değerlendirmesi, konuşma becerileri değerlendirmesi, anadilde konuşma performansı, yabancı dilde konuşma performansı

\title{
Introduction
}

"You should learn to think in English if you want to improve your speaking fluency." This is an utterance learners of English language hear a lot from their teachers when they start complaining about the problems they face while speaking in English. However, this may not always be possible as suggested in the quotation "Learning another language is like becoming another person" by Japanese author Haruki Murakami. It is indeed a challenging road to take for many English language learners especially in a foreign language context where the opportunities to use English are limited to classroom settings, yet great emphasis is put on communicative competence, i.e. using the language correctly and appropriately to communicate not being necessarily native-like (Brown, 1994). It may be worthwhile to explore how language learners perform in their native language in order to gain insights into whether they can be "another person" as mentioned in the quotation above while performing in English or they are the "same" person performing in a similar manner.

This study aims to investigate whether there is a correlation between language learners' performance in L1 and L2 when they are given the same tasks. 


\section{Literature Review}

It is a commonly accepted phenomenon that speaking is one of the most complex and difficult skills to acquire in another language (Tarone, 2005). As Bygate (1987) argues, speaking is not only the skill we carry out the basic transitions, but also the skill we are judged by other people no matter in which language we are communicating. Our ability to speak with confidence in carrying out the messages is continuously evaluated by others. As we speak, we not only use our linguistic and lexical knowledge but also make decisions of how to deliver the message across (Bygate, 1987). Nunan (1999) explains that we need to make decisions of which vocabulary to use in which grammatical structures as well as to decide on how to formulate the message depending on the person and the situation we are communicating in. Language learners need to be provided with the necessary environment in which they can experience all of these by being engaged in classroom activities (Johnson, 1995).

Various factors have been reported to affect the performance of learners while producing the foreign language. The most widely listed factors are as follows;

\section{L1 influence on L2 performance}

The influence of L1 on the acquisition of L2 has been widely discussed in the literature. It is acknowledged that transfer plays a vital role in shaping learners' interlanguage competence and performance (Ellis, 1994; Kohn, 1986). Language proficiency has been reported to have an effect on the influence of L1; learners at elementary level are reported to produce less transfer errors than intermediate or advanced level learners who, on the other hand, make more intralingual errors like overgeneralization (Taylor, 1975). According to Thornbury (2005) L1 and L2 speakers use similar mental processing stages; conceptualizing, formulating, articulating, self monitoring as well as attending to their interlocutors, adjusting messages and negotiating the conversational turns. Thus, he claims that these skills should be 
Anadolu Journal of Educational Sciences International, July 2016, 6(2)

transferable from the first language to the second. However, he thinks that because of the pressure of being accurate, learners overuse self-monitoring while producing in the second language.

Overusing the learners' first language in the environments where learners and teachers share the same mother-tongue has also been reported as a problem regarding L1 influence on L2 performance. As Harmer (2007) states, learners might end up with using their mother tongue whenever they feel incapable of expressing their ideas in the second one.

\section{Topical Knowledge}

It is clear that what a learner knows about a topic enables him to produce more language with reference to his knowledge of the topic (Bachman \& Palmer, 1999; Baker \& Westrup, 2003). Harmer (2007) argues that if students are asked to perform in the topics which they are not familiar with or which are not interesting for them, they have difficulty in performing.

\section{Performance conditions}

What makes speaking a challenging task is the time pressure of deciding what to say and how to say it by compensating for the difficulties (Bygate, 1987). While doing these in one's own language is not easy, trying to do all these in a classroom setting in another language makes it even more difficult. Nation and Newton (2009) list four types of conditions affecting the speakers' performance either negatively or positively; time pressure, planning, the standard of performance and the amount of support provided for the speaker.

\section{Language Anxiety}

Various affective factors are reported to have an impact on the learners' performance in another language, and language anxiety is one of the most cited reasons. Anxiety learners experience in a foreign language classroom environment affects learners' performance in a negative way (MacIntrye and Gardner, 1989). As Arnold and Brown (1999) point out, anxiety makes learners nervous and causes poor performance, which creates more anxiety and poorer 
performance in turn. Learners might feel anxious due to various reasons; having mature thoughts but immature language to express themselves; being afraid of criticism or losing face in front of their peers; having high expectations from themselves and evaluating their performance negatively can be counted as the reasons making learners anxious (Aydın, 2001; Krashen, 1982; Oxford, 1990; Tuan and Mai, 2015).

\section{Language Teachers}

Teachers' methodology, their attitudes towards students and their errors have long been discussed in language teaching. Expecting students to produce the language in front of everybody, asking them to perform without preparation, and comparing students' performances with each other cause learners to perform badly in learning a foreign language (Horwitz, Horwitz \& Cope, 1986). If the learners are not familiar with the activity or if they do not know what they are expected to do, they might also not perform as well as they wish (Aydın, 2001). Making presentations in front of everybody was found as the most anxietyprovoking activity type in Koch and Terrel's (1991) study. Horwitz (2008) argues that teachers are not tolerant with the silences in the classroom and tend to answer their own questions only after two seconds they ask a question creating pressure on learners' to come up with quick responses. Teachers' feedback to students' errors is also stated as a reason for students' poor performance in speaking tasks. Horwitz (2008) argues that second language teachers do not tolerate their learners' errors with the fear of fossilization. As Harmer (2007) states, if error correction is not done carefully considering the stages of the lesson and the type of the activity and the mistake and if the students are interrupted to correct their mistakes their flow of the speech may be affected negatively, and they may become demotivated and anxious. 
Anadolu Journal of Educational Sciences International, July 2016, 6(2)

\section{Culture}

The mismatches between the culture of the learners and teachers' methodology might be the source of the problems in some cases. As Harmer (2007) argues "good learning" methods for western cultures might differ from the ones for eastern cultures. Students in the eastern culture are generally reported to be reluctant to speak in classroom activities. He argues that if the students are not motivated to communicate and if they do not have anything to say, it might be because of their educational background rather than their lack of enthusiasm. Contrary to the findings about studies on eastern cultures, Xiaoshi \& Xueru (2006) claim that if teachers choose the topics attracting students' attention, if they can establish appropriate eye-contact with their learners and if they can create a relaxed atmosphere eastern students play an active role in the class activities and communicate eagerly.

As the literature suggests, speaking is a challenging skill to improve especially in a foreign language due to the factors stated above and Turkey is not an exception at all. In Turkey, as a foreign language context, a great amount of time, effort, and money is spent on learning English as a foreign language. Students start learning English at the second grade and are exposed to English with an average of 3 hours each week in the classroom. However, it is a widely accepted phenomenon that English language learning is problematic in Turkey because Turkish students still suffer from being able to perform in the language despite the amount of time spent on teaching it (Aktaş, 2005; Isık, 2008; Oğuz, 1999; Tosun, 2006; Paker, 2007; Tilfarlioğlu \& Ozturk, 2007; Enginarlar, 2003; Koru \& Akesson, 2011; YÖK, 2007; Board of the Directors of School of Foreign Languages; 2012). Statistical results also prove this situation. In 2012, the average TOEFL scores of Turkish exam takers comes in 75th place out of 100 countries, which is after countries like Sudan and Ethiopia that do not use Latin Alphabet (TEPA; 2011). In addition, according to EF English Proficiency Index (EPI) in 2015, Turkey is ranked 41 out of 60 countries, and in 2015 with a 47.62 average 
Anadolu Journal of Educational Sciences International, July 2016, 6(2)

Turkey takes its place as the 50th among 70 countries in the world. Apart from the fact that Turkey is a foreign language context for English language learners, studies conducted in Turkish context have identified various issues as problematic regarding the language learning process;

- $\quad$ the problems in curriculum design (Paker, 2007; Işık, 2008);

- the problems in the delivery of English teaching methods (Enginarlar, 2003; TEPAV, 2011; Aktaş, 2005);

- low language proficiency level of students (Yabancı Diller Yüksekokulları Yöneticiler Toplantıs1, 2012)

- efficacy of teachers, student interest and motivation, learning environment and learning materials (Aktaş, 2005)

The problems listed above have a negative impact on the higher education level in Turkey considering the fact that the medium of education in many universities in the country is English. As can be assumed, most universities' requirement of B2 level according to Common European Framework (CEFR) to start their education, and the fact that the majority of students start their university education with a very low proficiency level in English creates a big problem. According to a study conducted in Pamukkale University -a state university in Turkey- $94 \%$ of the students starting the preparatory year in the 2008 - 2009 academic year, $\% 87$ in $2009-2010$ and $82 \%$ of the students in 2010-2011 were placed at A1 level, the lowest proficiency level according to CEFR. This situation is almost the same in most of the state universities in the country. Therefore, providing language education in preparatory school becomes more than a challenging task to achieve. Students need to be proficient users of English to follow their departmental studies; however, it seems rather demanding to achieve this during preparatory year, which is generally an eight-month period. Given the circumstances, in a recent study, after visiting 38 universities, surveying 4300 students, 
Anadolu Journal of Educational Sciences International, July 2016, 6(2)

interviewing 400 teachers and observing 65 classes in 15 different cities, British Council (2015) reported the situation of English teaching in Turkish higher education. According to this report;

1. Universities where education is carried out in English are seen more prestigious than the ones where medium of education is Turkish; however, effective learning and teaching may not be fully achieved in some of these universities due to low English proficiency levels of students.

2. Preparatory schools do not design their curriculum that addresses the low proficiency level and low motivation of students, and do not prepare them for their academic studies.

3. Student-to-student interaction is not supported by some teachers, which in return affects students' progress in speaking gradually and results in diminish in the level of students' participation in class or academic discussions.

4. After studying hard for the university entrance exam, the preparatory year is generally considered as a time period when they have a stress-free, homework-free "off" year and students fail to see the need for English to follow their departmental studies.

5. $96 \%$ of the participants in the study acknowledge that English is a must to succeed in their departmental studies and get a better job in the future.

6. The observations of the lessons proved that opportunities for speaking activities are limited and the interaction is mostly teacher-student rather than student-student. Speaking is the skill that students have more difficulty than the other skills like reading.

The British Council report gives a broader picture of English language education in preparatory classes in a nutshell, and it is obvious that students suffer from speaking in 
Anadolu Journal of Educational Sciences International, July 2016, 6(2)

English due to low motivation and lack of opportunities for interaction in classes. Bayraktaroğlu (2012) argues that students are deprived of an educational environment that will support creativity and productivity in their mother tongue let alone doing this in a foreign language.

\section{The Aim of the Study}

The phenomenon described above is not an exception in Anadolu University. At Anadolu University, the medium of instruction is English in some faculties if not all; therefore, students should either provide a proof of their language proficiency such as a score from a national or international language proficiency exam or take the exemption exam administered at the beginning of the academic year and score above the cut point. However, a small number of students do well on these exams despite long years of English instruction they were delivered previously. The ones failing to pass the exemption exam are to take an eight-month intensive English preparatory class (hereafter Prep Class). Most of the students get a low mark on the Placement Test and thus are placed at A1 and A2 classes at the onset of the Academic Year. Taking this fact into consideration, it seems unlikely for such students to reach the level of a proficient language user so that they can follow the instruction in their faculty in English. Such learners have difficulty especially in producing the language when it comes to expressing their ideas on familiar topics even in classroom environment let alone under exam conditions.

This research particularly focuses on Prep school students' oral performance given the fact that speaking is the most complex ability to acquire in a foreign language due to various reasons stated previously and the language teaching process does not provide a flourishing environment to improve it.

"I would perform better if it were in Turkish!"

\section{Anonymous}


Anadolu Journal of Educational Sciences International, July 2016, 6(2)

This single utterance itself above, expressed by numerous Prep School students, serves as the triggering motive of this study. Referring to the Murakami quote at the very beginning, does this utterance mean that our students fail to become "another person" in their learning process and perform poorly when speaking English? Would they really perform better in Turkish? Taking this into consideration, the main assumption behind this study is that if students did not perform well in English, they were assumed to perform the same with the same task in Turkish referring to the quote by Ludwig Wittgenstein "The limits of my language are the limits of my world". Thus, this study seeks to answer the following research questions:

1. Are there any differences between students' oral performance in English (L2) and Turkish (L1)?

2. Does language proficiency in L2 make any difference in students' oral performance in L1 and L2?

3. Are there any differences between the participants' L1 and L2 scores regarding the components on the speaking rubric namely, "Task Achievement", "Fluency", "Grammatical Competence", "Lexical Competence" and "Interaction"?

4. How do students feel while performing in L1 and L2?

\section{Methodology}

\section{The Setting and Participants}

The study was conducted in the School of Foreign Languages at Anadolu University (AUSFL) in Turkey. Every year AUSFL hosts almost 2500 students learning English as a foreign language. The students are expected to be competent in four main language skills as well as subskills like grammar and vocabulary.

In the study, the participants (aged between 19 and 24) were 35 EFL learners studying English at AUSFL in 2014-2015 Academic Year, Spring Term. The participants were from 
Anadolu Journal of Educational Sciences International, July 2016, 6(2)

two different language levels $\mathrm{B} 1(\mathrm{~N}=18)$ and $\mathrm{B} 2(\mathrm{~N}=17)$, who were placed in these levels according to the scores they took on the Placement Test given at the beginning of the academic year. The number of teaching hours for students in each level are the same. They take classes from three different English language instructors and follow a certain course book.

\section{Data Collection Procedures}

The initial step in the data collection procedure was to prepare the test items used to assess the participants' speaking performance. In order to do this, two sets of questions were prepared both in English and in Turkish. Set 1 included questions about familiar topics that the learners would respond individually. In Set 2, the learners were expected to interact with each other about a question with picture prompts.

Sample items from Set 1:

“What are your plans for this summer? Explain”.

"What makes you happy in life? Give examples".

Sample item from Set 2:

"What kind of movies do you prefer? Why? Discuss with your partner."

Before the interviews, the participants were informed about the rubric they would be evaluated on. It basically had five components; namely, task achievement, fluency, grammatical competence, lexical competence, and interaction.

Students were invited to participate in an exam simulation one week before the actual exam in order to help them diminish their anxiety level and have an opportunity to practice speaking the foreign language. In order to simulate the exact exam setting, the participants were paired randomly and taken to the exam room where they were assessed by two separate raters while being video recorded. The aim of the study was not revealed to the raters, and they were only told that it was to provide the learners with an exam simulation. The rubric used for grading 
oral performance during the Academic Year was used in the study (see Appendix 1 for the procedures of the speaking exam.).

To prevent familiarity effect, the English and the Turkish version of the exams were held with a minimum 5-week intervals and the participants were not told that they would receive the same exam questions in their own language.

Once the exam procedure in English was completed, an online survey was given to the participants. The aim of this survey was to reveal students' perceptions of the speaking exam and their feelings before, during and after the exam procedure.

After a minimum five-week interval, the same procedure was followed in Turkish with the same participants and raters.

\section{Data Analysis Procedures}

The data collected was analyzed both quantitatively and qualitatively in order to provide answers to the research questions. First of all, a paired samples t-test was computed to find if the participants' performance differed in L1 and L2. Then, a Pearman rho Correlation analysis was run with the students' scores they got in L1 and L2 collected from two different language levels to find out if language proficiency made any difference in their performances in both languages. Third, Chi-square test was computed to see learners' performance regarding each component of the rubric used to assess the learners' performance in both languages. Finally, the feelings of the participants regarding their performance in both languages were analyzed using content analysis.

\section{Results}

The primary aim of the study was to explore whether the participants' performance differed in English and Turkish. The assumption was that if the participants had difficulty in responding to a question in English, they would perform similarly in their own language regarding the 
Anadolu Journal of Educational Sciences International, July 2016, 6(2)

same question. Therefore, the paired samples t-test was computed to find out whether participants performed differently in L1 and L2. The results are presented in Table 1 below.

Table 1

Students ' performance in L1 and L2

\begin{tabular}{|c|c|c|c|c|c|c|c|c|}
\hline & \multicolumn{5}{|c|}{ Paired Differences } & \multirow[t]{2}{*}{$\mathrm{t}$} & \multirow[t]{2}{*}{ df } & \multirow[t]{2}{*}{$\begin{array}{l}\text { Sig. (2- } \\
\text { tailed) }\end{array}$} \\
\hline & Mean & $\mathrm{Sd}$ & $\begin{array}{l}\text { Std. } \\
\text { Error } \\
\text { Mean }\end{array}$ & $\begin{array}{l}95 \% \\
\text { Interval } \\
\text { Difference }\end{array}$ & $\begin{array}{l}\text { onfidence } \\
\text { of the }\end{array}$ & & & \\
\hline & & & & Lower & Upper & & & \\
\hline $\begin{array}{l}\text { L2 } \\
\text { score- } \\
\text { L1 } \\
\text { score }\end{array}$ & $-3,25$ & 2,396 &, 424 & $-4,11$ & $-2,39$ & $-7,672$ & 31 &, 000 \\
\hline
\end{tabular}

As seen in Table 1, there was a significant difference between the participants' performance in English and Turkish. In other words, contrary to the pre-assumption that subjects would perform the same in both languages, they performed better in their first language than they did in their foreign language.

The second research question attempted to answer if foreign language proficiency made any difference in students' oral performance in L1 and L2. To answer this question, the correlation between students' scores in L1 and L2 in two different levels were identified. Table 2 below gives the results for students' performance at different proficiency levels.

Table 2

Level B1-B2-Correlations

\begin{tabular}{lllll}
\hline & B1 & & B2 & \\
\hline & L2 Score & L1 Score & L2 Score & L1 Score \\
Spearman's rho L2 Score Correlation & 1.000 &, $669 * * *$ & 1.000 &, 426 \\
$\begin{array}{l}\text { Coefficient Sig. (2-tailed) } \\
\text { N }\end{array}$ & 18 &, 005 & 100 \\
L1 Score Correlation Coefficient &, $669 * *$ & 1,000 &, 426 & 16 \\
$\begin{array}{l}\text { Sig. (2-tailed) } \\
\text { N }\end{array}$ &, 005 & 16 &, 100 & 1,000 \\
$\quad$ & 16 & 16 & 16 & 16 \\
\hline & $* * *$ Correlation is significant at the 0,01 level (2-tailed)
\end{tabular}


As seen in Table 2, the participants at B1 level performed significantly better in their first language than they did in English. On the other hand, according to the results presented in same table, there is no significant difference between the performance of B2 level students in English and Turkish. That is, learners with lower proficiency level performed better in their first language while learners' with higher proficiency level did not reveal any differences in their performance in L1 and L2.

The third research question aimed to find out whether there were any differences between the scores regarding the components on the speaking criteria when their performance in L1 and L2 was compared. As stated earlier, there were five components named as "Task Achievement", "Fluency", "Grammatical Competence”, "Lexical Competence" and "Interaction", and each participant was graded by two separate raters. In order to provide an answer to the third research questions, Chi-square test was run using the scores given for their performance in L1 and L2 and the results showed that there was no significant difference between the scores regarding each component.

Table 3 shows the Chi-square statistics of the Task Achievement component of the criteria. Task Achievement is about whether the test-taker effectively addresses the topic and develops it with a wide range of details such as explanations and/or exemplifications. The scores for this component are given out of six, 4 referring to the moderately developed response with some details missing. As seen in Table 3, no significant difference has been found between the two group (B1 and B2 level students) regarding their L1 and L2 performance in this specific component. 
Anadolu Journal of Educational Sciences International, July 2016, 6(2)

Table 3

Task achievement

\begin{tabular}{|c|c|c|c|c|c|c|c|}
\hline \multirow[b]{2}{*}{ Level } & \multirow[b]{2}{*}{ Component } & & & \multicolumn{4}{|c|}{ Task Achievement in L1 } \\
\hline & & \multicolumn{2}{|c|}{ Score } & 4 & 5 & 6 & Total \\
\hline \multirow{10}{*}{ B1 } & \multirow{10}{*}{ Task Achievement in L2 } & 2 & Count & 1 & 0 & 0 & 1 \\
\hline & & & $\%$ of Total & $6,3 \%$ & $0,0 \%$ & $0,0 \%$ & $6,3 \%$ \\
\hline & & 3 & Count & 0 & 2 & 1 & 3 \\
\hline & & & $\%$ of Total & $0,0 \%$ & $12,5 \%$ & $6,3 \%$ & $18,8 \%$ \\
\hline & & 4 & Count & 1 & 1 & 0 & 2 \\
\hline & & & $\%$ of Total & $6,3 \%$ & $6,3 \%$ & $0,0 \%$ & $12,5 \%$ \\
\hline & & 5 & Count & 0 & 1 & 5 & \\
\hline & & & $\%$ of Total & $0,0 \%$ & $6,3 \%$ & $31,3 \%$ & $37,5 \%$ \\
\hline & & 6 & Count & & & 2 & \\
\hline & & & $\%$ of Total & $0,0 \%$ & $12,5 \%$ & $12,5 \%$ & $25,0 \%$ \\
\hline \multirow{5}{*}{ B2 } & \multirow{5}{*}{ Task Achievement in L2 } & 4 & Count & & 1 & 0 & 1 \\
\hline & & & $\%$ of Total & & $6,3 \%$ & $0,0 \%$ & $6,3 \%$ \\
\hline & & 5 & Count & & & & \\
\hline & & & $\%$ of Total & & $18,8 \%$ & $18,8 \%$ & $37,5 \%$ \\
\hline & & 6 & $\begin{array}{l}\text { Count } \\
\% \text { of Total }\end{array}$ & & $\begin{array}{l}4 \\
25,0 \%\end{array}$ & $\begin{array}{l}5 \\
31,3 \%\end{array}$ & $\begin{array}{l}9 \\
56,3 \%\end{array}$ \\
\hline
\end{tabular}

*Chi-square Level B1: 0,696 P>0,05; Level B2: 0,255 P>0,05

The second component on the criteria used is about the fluency of the test-takers, which mainly focuses on whether the test-taker speaks smoothly with little hesitation without interfering with communication. The raters give 3,2 or 1 depending on the test-taker's performance. As seen in Table 4, no chi-square statistics was computed because all the students got the highest score for fluency for their performance in L1 and it was a constant.

Table 4

Fluency

\begin{tabular}{|c|c|c|c|c|c|}
\hline \multirow[b]{2}{*}{ Level } & \multirow[b]{2}{*}{ Component } & & & \multicolumn{2}{|c|}{ Fluency in L1 } \\
\hline & & \multicolumn{2}{|c|}{ Score } & 3 & Total \\
\hline \multirow{6}{*}{ B1 } & \multirow{6}{*}{ Fluency in L2 } & 1 & Count & 2 & 2 \\
\hline & & & $\%$ of Total & $12,5 \%$ & $12,5 \%$ \\
\hline & & 2 & Count & 10 & 10 \\
\hline & & & $\%$ of Total & $62,5 \%$ & $62,5 \%$ \\
\hline & & 3 & Count & 4 & 4 \\
\hline & & & $\%$ of Total & $25,0 \%$ & $25,0 \%$ \\
\hline \multirow{4}{*}{ B2 } & \multirow{4}{*}{ Fluency in L2 } & 2 & Count & 4 & 4 \\
\hline & & & $\%$ of Total & $25,0 \%$ & $25,0 \%$ \\
\hline & & 3 & Count & 12 & 12 \\
\hline & & & $\%$ of Total & $75,0 \%$ & $75,0 \%$ \\
\hline
\end{tabular}

*Chi-square Level B1: 0,000 P>0,05; Level B2: no statistic was computed 
Table 5 illustrates the Chi-square statistics of the component "Grammatical Competence", which is basically about the accurate use of language forms. Little mistakes in the use of grammar rules are tolerated as long as the meaning conveyed is clear, and the scores are given between 4-1. As seen in the table, there is no significant difference regarding B1 level students' performance in their grammatical competence. However, for B2 level students no statistics could be computed because the score they got for grammatical competence in L1 was a constant.

Table 5

Grammatical competence

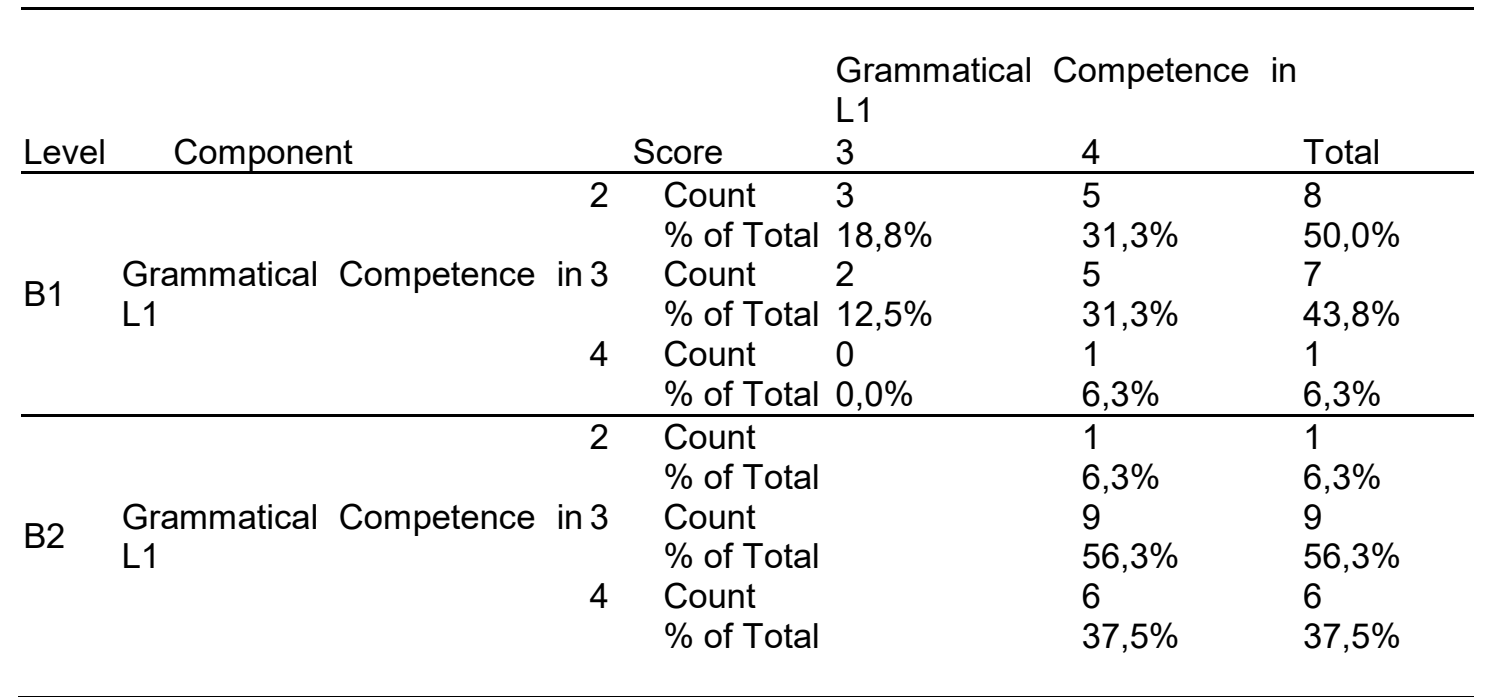

*Chi-square Level B1: 0,194 P>0,05; Level B2: no statistics was computed

Lexical competence, the forth component on the criteria is about the use of appropriate and accurate use of vocabulary; though, some inaccuracies regarding word choice, word form or misuse of words are ignored as long as the meaning is fully clear, and the scores are given between 4-1. As seen in Table 6, the scores that the students in both levels got regarding lexical competence did not differ significantly. 
Anadolu Journal of Educational Sciences International, July 2016, 6(2)

Table 6

Lexical competence

\begin{tabular}{|c|c|c|c|c|c|c|}
\hline \multirow[b]{2}{*}{ Level } & \multirow[b]{2}{*}{ Component } & \multirow[b]{2}{*}{ Score } & & \multicolumn{3}{|c|}{ Lexical Competence in L1 } \\
\hline & & & & 3 & 4 & Total \\
\hline \multirow{6}{*}{ B1 } & \multirow{6}{*}{ Lexical Competence in L2 } & 2 & Count & 2 & 4 & 6 \\
\hline & & & $\%$ of Total & $12,5 \%$ & $25,0 \%$ & $37,5 \%$ \\
\hline & & 3 & Count & 0 & 9 & 9 \\
\hline & & & $\%$ of Total & $0,0 \%$ & $56,3 \%$ & $56,3 \%$ \\
\hline & & 4 & Count & 0 & 1 & 1 \\
\hline & & & $\%$ of Total & $0,0 \%$ & $6,3 \%$ & $6,3 \%$ \\
\hline \multirow{4}{*}{ B2 } & \multirow{4}{*}{ Lexical Competence in L2 } & 3 & Count & 3 & 7 & 10 \\
\hline & & & $\%$ of Total & $18,8 \%$ & $43,8 \%$ & $62,5 \%$ \\
\hline & & 4 & Count & 0 & 6 & 6 \\
\hline & & & $\%$ of Total & $0,0 \%$ & $37,5 \%$ & $37,5 \%$ \\
\hline
\end{tabular}

*Chi-square Level B1: 0,439 P>0,05; Level B2: 0,349 P>0,05

Table 7 shows the scores that the students at both levels got in the interaction component, which is defined as "interaction is well developed and mostly kept alive" for the highest score 3. As seen in Table 7, no significant difference was found in both level and in both languages. Table 7

\section{Interaction}

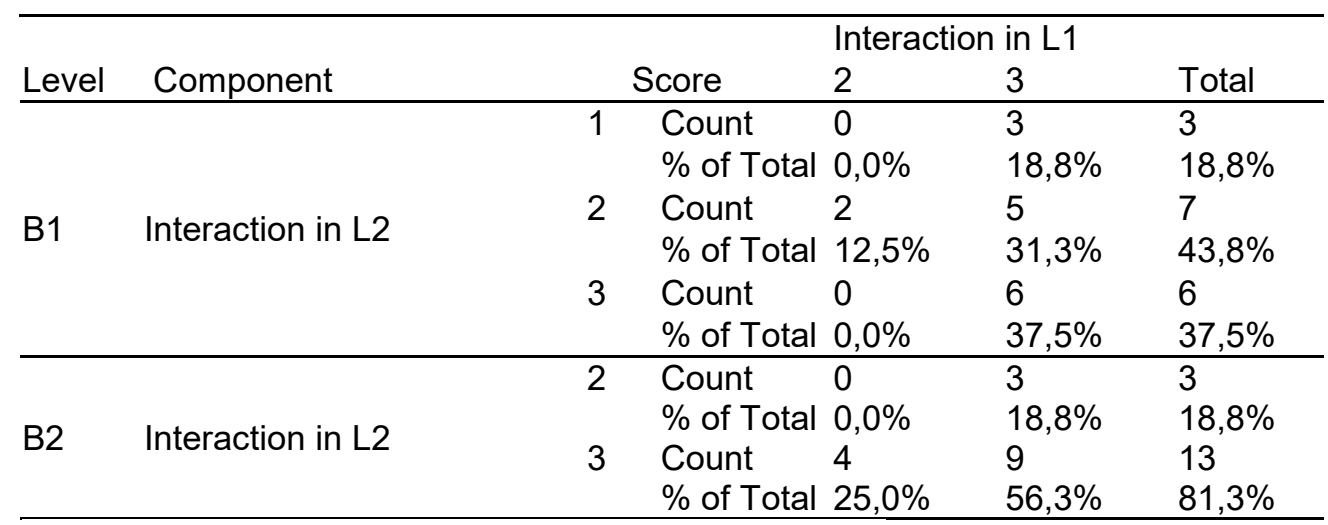

*Chi-square Level B1: 0,394 P>0,05; Level B2: 0,267 P>0,05

The final research question was about the feelings of the participants regarding their performance in both languages, which aimed to find out whether their feelings influenced their performance. The content analysis of the responses to the online survey given and the follow-up interviews conducted after their performance revealed that the participants had low levels of anxiety as illustrated in the following extracts.

"... I was less nervous here .... It was better than the actual exam...." 
Anadolu Journal of Educational Sciences International, July 2016, 6(2)

“... I haven't made a lot of mistakes. We feel more pressure in the actual speaking exams... scores..."

“... I was better than the actual exam. I felt very nervous then. I am usually nervous. .... but I felt better here. ..."

"... I was nervous before the exam, to be honest, but I felt comfortable when I was in the exam room. ...."

The participants also expressed their feelings about performing in Turkish, which was a totally new experience to them, so they had a mixture of feelings either related to their performance in Turkish or the thinking / speaking process they went through as seen in the following extracts.

"I was not nervous, but I tended to say things in English like because. I wanted to speak in English. I wanted to tell things in English. I actually thought in English first and translated it into Turkish then."

“Well, I don't know. I felt awkward in Turkish. It was more purposeful in English. I felt like it was not so in Turkish. But it was good anyway."

"It's easy because it is in Turkish. We can talk as we like-fluently, but when it is in English, it is more difficult to say them. So it is more comfortable now."

\section{Discussion}

This research tried to find the relationship between the learners' performance in their first and foreign language. It was assumed that learners who experience difficulties in expressing themselves in the foreign language would experience similar difficulties in expressing themselves in their own language as well. The results of the study did not prove this assumption as learners, with a lower L2 proficiency level performed better in their first language. Their performance was not regarded differently according to different components 
on the speaking rubric. Also, learners' performance at a higher L2 proficiency did not differ in both languages.

There may be various reasons why the participants performed better in Turkish:

a. The study was conducted in the Spring Term of the academic year. The participants had already taken two oral exams and had done several speaking tasks in English before the study was conducted. This might have helped them in performing better in both languages. Applying the strategies they learned in their foreign language learning experience (e.g. providing enough support; giving concrete examples and maintaining interaction with the other speakers such as making eye contact) might have had a positive impact on their performance in expressing their ideas in Turkish as well. The results would have been different if the study had been conducted at the beginning of the academic year, i.e. before the students had less experience in speaking in English.

b. The participants having taken the English version of the exam might have resulted in a better performance in Turkish. Some participants expressed that they tried to remember their previous responses in English when they were to answer the same question in Turkish. They also stated that they tried to elaborate what they lacked in their performance in English as seen in the following extracts:

"Sir, they were the questions [that] we knew [the answers of]. I remember my answers from the previous exam. ..."

"The second question... What was it? Something about job. I added a few more things in Turkish. I couldn't have remembered them [in the English version] ... you know ... I don't like working in an office. I have told them. ..."

c. The atmosphere created for this speaking exam might be another reason explaining the subjects' high scores; they all stated that since this was not the real exam situation they were relaxed. As they stated, not feeling anxious helped their performance in a positive way. 
Anadolu Journal of Educational Sciences International, July 2016, 6(2)

The results of the study also showed that learners with a higher proficiency performed better in both languages. It might be possible to infer that as learners have spent more time in the foreign language learning process they became more familiar with the necessary strategies to express themselves. This strategy training might have helped learners perform better in their first language as well.

To sum up, the assumption that learners who experience difficulties in expressing themselves in the foreign language will experience similar difficulties in expressing themselves in their own language has not been proved; learners with low proficiency levels expressed themselves better in their own language.

\section{Conclusion and Implications}

The aim of the study was to explore if performing in the learners' native and foreign language would make any difference in their speaking. From the results of the study it can be concluded that the education given in L2 may be utilized in performing in L1 as well. In this study, the experience of the participants in speaking English has a positive impact on their performance in Turkish. This may support what Thornbury states about the transferability of mental processing stages from L1 to L2 or vice versa (2005). Similarly, the participants' better performance in L1 may be the result of their familiarity to the topics asked in the exam simulation. Because the questions were exactly the same in the L2 and L1 versions in the study, they did not have any difficulty in performing in L1, which illustrates the positive effect of topic familiarity on speaking performance (Bachman \& Palmer, 1999; Baker \& Westrup, 2003; Harmer, 2007). In addition, language anxiety, as a major factor affecting speaking performance, is less observed in this study, which might have resulted in better performance in both L1 and L2. Although some of the participants scored relatively lower 
than their peers, as this simulation was thought to prepare them for the actual exam, rather than being anxious, they considered it a good opportunity to improve their performance.

As a result, it would be possible to conclude that due to the intensive language instruction and strategy training, the subjects in this study were able to perform well in both languages. Learners were also observed transferring the strategies they learned in L2 while producing in their first language. It was also found that the more proficient the learners in the foreign language, the better results they get in producing both L1 and L2. Therefore, it would be possible to imply that equipping learners with necessary strategies will help them facilitate their production.

The overall conclusion to draw from the results of the study might be what hinders students perform better in a foreign language is not the language barrier but the strategies they use while speaking. If various situations like the exam simulation in this study are created in foreign language contexts and students are encouraged to participate in them and reflecting afterwards, it is very likely to have an increase in their speaking performance. In addition, raising awareness of the students' on language learning process, creating a friendly and anxiety-free environment as well as increasing students' familiarity to the exam procedures will definitely increase the quality of their performance.

\section{Limitations}

The study was conducted with a limited number of students in the spring term of the academic year. The result would have been different if the study had been conducted with a larger sample of English language learners at the beginning of the academic year without providing them training to improve their speaking skills and before they become familiar with the speaking exam procedures. In addition to this, conducting the study in L1 first then in L2 would have proved different results. 
Anadolu Journal of Educational Sciences International, July 2016, 6(2)

Another limitation of the study was about using the same speaking criteria for both exams. The raters stated experiencing difficulties in evaluating students' performance in L1. Since it was the first time they were asked to perform such a task and since the criteria was developed for L2 performance evaluation, teachers found evaluating especially learners' grammar and vocabulary knowledge difficult, as seen in the following extracts;

“... It is the first time I'm grading a student's performance in Turkish. How am I going to assess his grammar usage? ... That's really tough!..."

“... When it comes to 'task achievement, it is okay. ... Easier to assess his performance in Turkish, then. But, grammar and vocabulary, that's difficult. ..."

“... How should I grade their grammatical competence, then? Whatever he says seems quite appropriate to me. ..."

The confusion of the raters might have been minimized if they had been informed that the procedure would be in Turkish and they were to use the same rubric at the very beginning of the study. Although they were already familiar with the rubric, having a norming session to discuss how to interpret each component in Turkish would prove a smooth rating process. According to $\mathrm{Oz}$ (2016) teachers should adopt strategies that help their students to improve and strengthen their L2 self image which will, in turn, increase linguistic self-confidence in L2 learners and enhance their L2 motivation, resulting in enhanced L2 communication. 
Anadolu Journal of Educational Sciences International, July 2016, 6(2)

\section{Appendices:}

\section{$\underline{\text { Appendix 1: Exam Procedure }}$}

\section{Exam Procedure followed in the study}

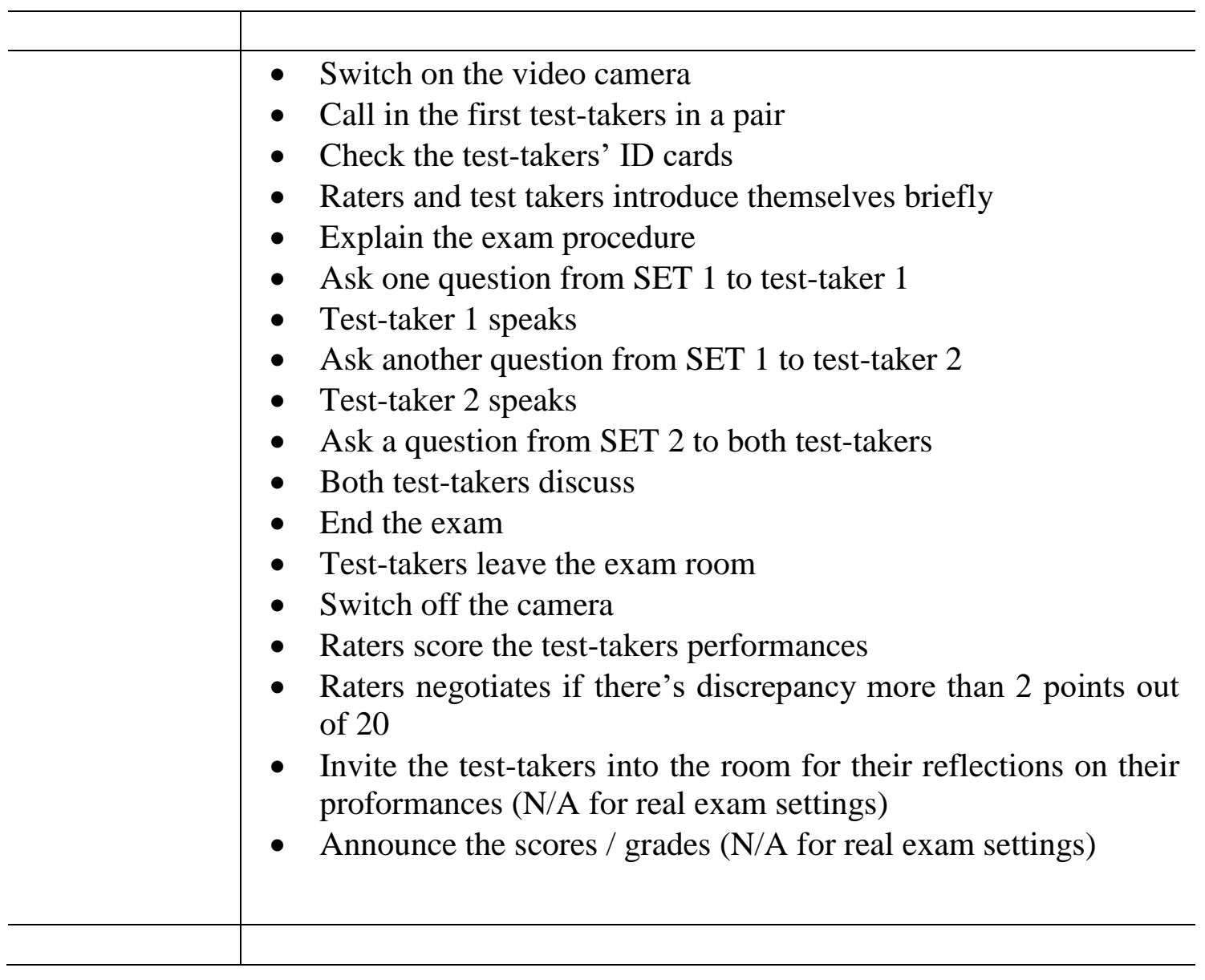


Anadolu Journal of Educational Sciences International, July 2016, 6(2)

\section{References}

Arnold, J., \& Brown, H. D. (1999). A map of the terrain. In Arnold, J. (Ed.), Affect in language learning. (pp. 1-24).Cambridge: CUP.

Aydın, B. (2001). A study of sources of foreign language classroom anxiety in speaking and writing classes. Eskişehir: Anadolu Üniversitesi Yayınları, No: 12

Bachman, L., \& Palmer, A.S. (1996). Language testing in practice. Oxford: Oxford University Press.

Baker, J., \& Westrup, H. (2003). Essential speaking skills: A handbook for English language teachers. London: Continuum.

Bayraktaroğlu, S. (2012). Yabancı dil eğitimi gerçeği, yabanci dilde eğitim yanilgisi. Türkiye'de yabancı dil eğitimde eğitim ne olmalı? 1. Yabancı Dil Eğitimi Çalıştayı Bildirileri. 12-13 Kasım 2012. Ankara: Hacettepe Universitesi Yayınlart. 2014

British Council (2015). The state of English in higher education in Turkey. A baseline study. Yorum Basın Yayın Sanayi Ltd. Şti, Ankara.

Brown, H. D. (1994). Teaching by principles. An interactive approach to language pedagogy. New Jersey: Prentice Hall Regents.

Bygate, M. (1987). Speaking. C.N. Candlin \& H. G. Widdowson (Eds.). Langauge Teaching: A scheme for teacher education. Oxford: Oxford University Press.

EF English Proficiency Index 2015 (2015). Retrieved December, 2015, from http://www.ef.com.tr/epi/

Ellis, R. (1994). The study of second language acquisition. Oxford: Oxford University Press. 
Anadolu Journal of Educational Sciences International, July 2016, 6(2)

Harmer, J. (2007). The practice of English language teaching. Pearson Education Limited: Essex.

Horwitz, E. K. (2008). Becoming a language teacher. A practical guide to second language learning and teaching. Boston. Pearson Education, Inc.

Horwitz, E. K., Horwitz, M. B., \& Cope, J. A. (1986). Foreign language classroom anxiety. The Modern Language Journal, 72 (3), 283-294.

Yabancı Diller Yüksekokulları Yöneticileri Toplantısı. Retrieved December 15, 2015 from https://ydyotr.wordpress.com/toplantilar/

Johnson, K.E. (1995). Understanding communication in second language classroom. Cambridge: Cambridge University Press.

Koch, A. S., \& Terrell, T. D. (1991). Affective reasons of foreign language students to natural approach activities and teaching techniques. In Horwitz, E. K. \& Young, D. J (Eds.), Language anxiety (pp. 109-125). London. Prentice-Hall International (UK).

Kohn, K. (1986). The analysis of transfer. In E. Kellerman \& M. Sharwood Smith (Eds.), Crosslinguistic influence in second language acquisition (pp. 21-34). New-York: Pergamon Press.

Krashen, S. D. (1982). Principles and practice in second language acquisition. New York: Pergamon Press.

MacIntyre, P. D., \& Gardner, R. C. (1989). Anxiety and SLL. Toward a theoretical clarification. Language Learning, 39 (2), 251-75. 
Anadolu Journal of Educational Sciences International, July 2016, 6(2)

Nation, I. S. P., \& Newton, J. (2009). Teaching ESL /EFL listening and speaking. ESL \& Applied linguistics professional series. Routledge: Taylor \& Francis Group.

Nunan, D. (1999). Second language teaching \& learning. Boston, MA: Heinle \& Heinle Publishers.

Oxford, R. L. (1990). Language learning strategies: What every teacher should know. New York. Newbury House Publishers.

Tarone, E. (2005). Speaking in a second language. In E. Hinkel (Ed.) Handbook of research in second language teaching and learning (pp. 485-502). London: Lawrence Erlbaum.

Tuan, N. H., \& Mai, T. N. (2015). Factors affecting students' speaking performance at Le Thanh Hien High School. Asian Journal of Educational Research, 3 (2). Retrieved December 11, 2015, from _http://www.multidisciplinaryjournals.com/wpcontent/uploads/2015/03/FACTORS-AFFECTING-STUDENT'S-SPEAKING.pdf

Xiaoshi, L., \& Xueru, L. (2006). Why don't you speak up?: East Asian students' participation patterns in American and Chinese ESL classrooms. Intercultural Communication Studies, 15 (1). Retrieved December 2, 2015, from http://web.uri.edu/iaics/files/19-Xiaoshi-Li$\underline{\text { Xuerui-Jia.pdf }}$

Taylor, B. P. (1975). The use of overgeneralization and transfer learning strategies by elementary and intermediate students of ESL. Language Learning, 25, 73-107. 